\title{
Exocrine Pancreatic Cancer Pathologic Primary Tumor TNM Finding v6
}

National Cancer Institute

\section{Source}

National Cancer Institute. Exocrine Pancreatic Cancer Pathologic Primary Tumor TNM

Finding v6. NCI Thesaurus. Code C60938.

A pathologic finding about one or more characteristics of exocrine pancreatic cancer, following the rules of the TNM AJCC v6 classification system as they pertain to staging of the primary tumor. 